Journal of the Society for the Study of Architecture in Canada Le Journal de la Société pour l'étude de l'architecture au Canada

\title{
Formerly Known as the Glass Ceiling
} Engaging Gender Inequity through Design-Build Pedagogy

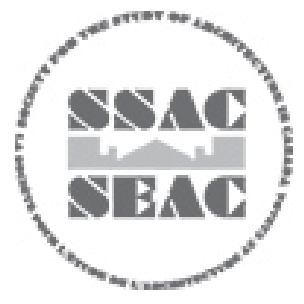

\section{Marina Schwellnus et Thomas Strickland}

Volume 44, numéro 1, 2019

URI : https://id.erudit.org/iderudit/1066284ar

DOI : https://doi.org/10.7202/1066284ar

Aller au sommaire du numéro

Éditeur(s)

SSAC-SEAC

ISSN

2563-8696 (numérique)

Découvrir la revue

Citer cet article

Schwellnus, M. \& Strickland, T. (2019). Formerly Known as the Glass Ceiling:

Engaging Gender Inequity through Design-Build Pedagogy. Journal of the

Society for the Study of Architecture in Canada / Le Journal de la Société pour

l'étude de l'architecture au Canada, 44(1), 75-84.

https://doi.org/10.7202/1066284ar d'utilisation que vous pouvez consulter en ligne. 


\section{FORMERLY KNOWN AS THE GLASS CEIUNG Engaging Gender Inequity through Design-Build Pedagogy}

MARINA SCHWELLNUS is currently completing her Master of Architecture at Laurentian University. She has been the recipient of multiple scholarships, including the F. Jean MacLeod Architecture Scholarship. She participated in the 2016 Bergen International Wood Festival, published a drawing in Landscapes / Paysages: Landscape Architecture in Canada, and presented a paper on the installation Formerly Known as the Glass Ceiling, with Thomas Strickland, at the 2018 Society for the Study of Architecture in Canada conference.

THOMAS STRICKLAND is an assistant professor in the McEwen School of Architecture. He has written for numerous art and architectural journals and recently published a chapter in Healing Spaces, Modern Architecture, and the Body. He also works as an artist. Recent exhibits include Breathing Grid, Leave Your Shame Here, Formerly Known as the Glass Ceiling, and a collaboration with the Northern Ontario School of Medicine, Noojamada

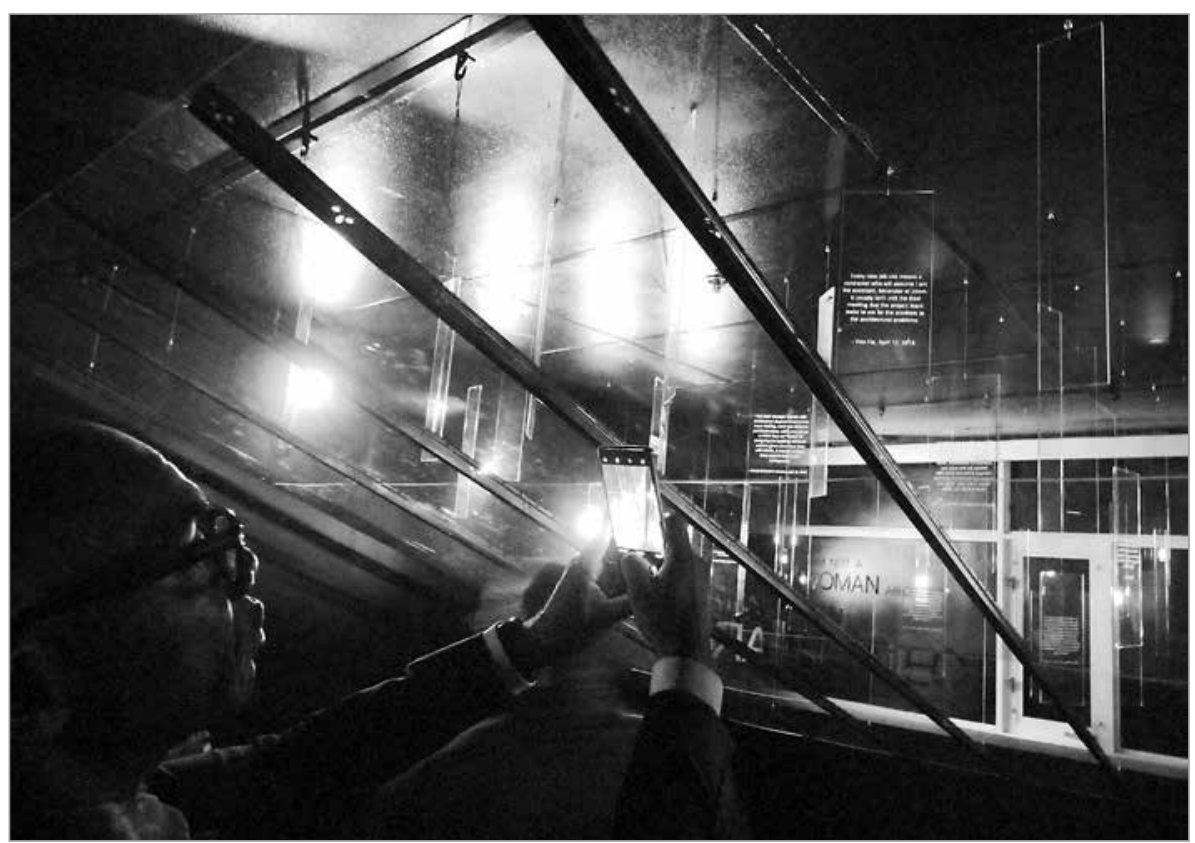

FIG. 1. INSTALLATION FORMERLY KNOWN AS THE GLASS CEILING BEING PHOTOGRAPHED DURING THE MOVE: BIG INSTALLATION PARTYAT THE OAA HEADQUARTERS. | ॥HF, 2007.

\author{
$>$ MARINA SCHWELLNUS AND \\ THOMAS STRICKLAND
}

$\mathrm{O}^{2}$ September 15, 2017, the Ontario Association of Architects (OAA) held MOVE: Big Installation Party, a public event designed to launch renovations to their headquarters at 111 Moatfield Drive in Toronto. Completed in 1992, the building was the product of a highly publicized, province-wide design competition won by the young architect Ruth Cawker. In 2014, the OAA committed to a comprehensive retrofit of the building led by architect David Fujiwara, ${ }^{1}$ with the intention of meeting net zero energy standards by 2030. Taking advantage of the temporarily vacated structure, MOVE's curator Esther Shipman assembled teams from Ontario's five schools of architecture and a number of young practices, giving each the opportunity to create installations showcasing new design directions, talents, and skills. To foster the bond between the OAA and emerging architects, Shipman personally invited schools of architecture. In part the event sought to send a message that, while the OAA is an administrative and regulatory body, it is also a venue in which a new generation of designers can share ideas and manifest ambitions. ${ }^{2}$

The McEwen School of Architecture (MSOA) assembled a team of four undergraduate students, Matt Hunter, Chris Baziw, Jeremy Upward, and Marina Schwellnus, and one professor, Thomas Strickland, to design and construct an installation. ${ }^{3}$ The team took the opportunity of MOVE to examine the issue of gender inequity in architecture through both their approach to and the content of their installation. MSoA team's position was galvanized by the fact that the 


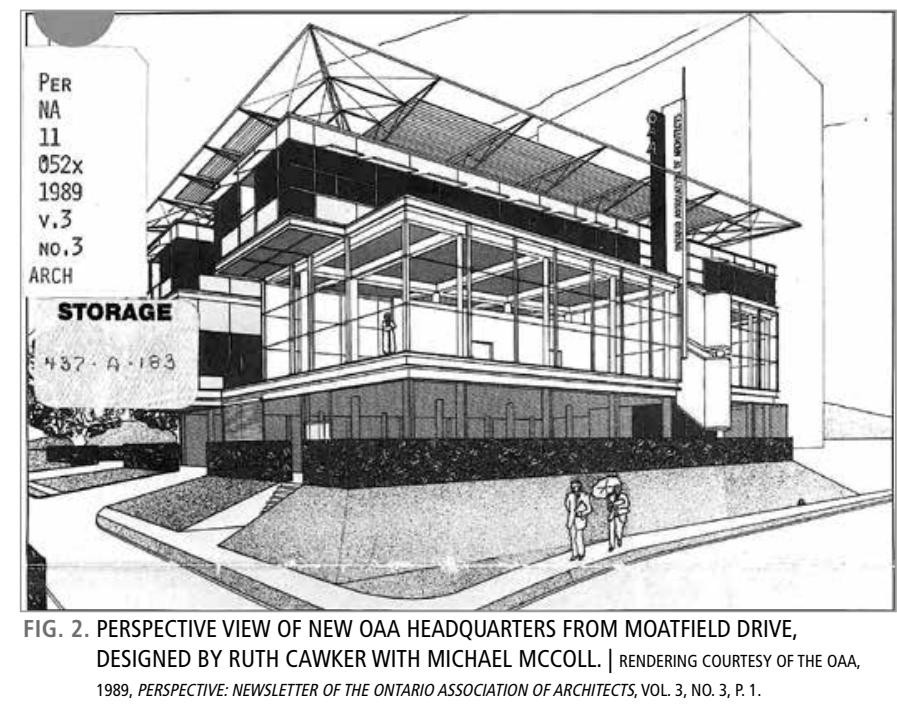

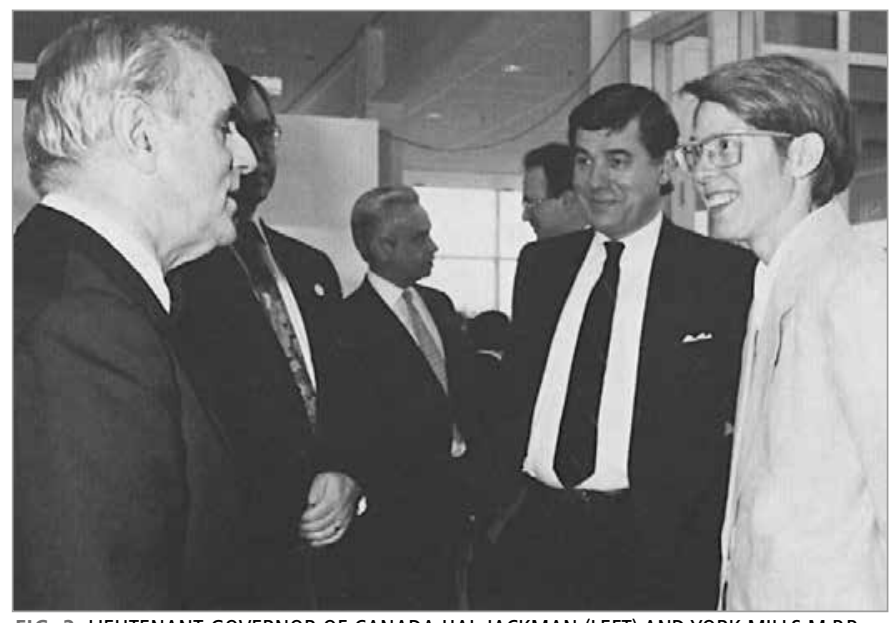

FIG. 3. LIEUTENANT GOVERNOR OF CANADA HAL JACKMAN (LEFT) AND YORK MILLS M.P.P. DAVID TURNBULL CHAT WITH RUTH CAWKER AFTER THE OFFICIAL OPENING CEREMONIES OF THE NEW OAA HEADQUARTERS. | IMAGE COURTESY OF THE OAA, 1992, PERSPECTIVE: NEWSLETTER OF THE ONTARIO ASSOCIATION OF ARCHITECTS, VOL. 6, NO. 2, P. 1.
OAA building was a celebrated design by a woman architect, and yet, nearly thirty years after the new headquarters opened, women still seek professional parity. MSoA used their installation to draw attention to this ongoing struggle within the architectural profession and education. The project, named Formerly Known as the Glass Ceiling (fig. 1), began by group members asking each other a question: how can gender inequity in the architectural profession be revealed through design? What follows is a report, written by team members Thomas Strickland and Marina Schwellnus, on our exploration of the issue through the installation's design-build process.

\section{THE ONTARIO ASSOCIATION OF ARCHITECTS HEADQUARTERS}

The headquarters of the Ontario Association of Architects (OAA) has been associated with cutting-edge architectural ideas since the 1950s. The pre-1992 headquarters building, a simple brickclad box poised atop a glass enclosure set into a sloping site at 50 Park Road, was the competition-winning design by John B. Parkin Associates in 1954. At the time of its construction the building was recognized as a "landmark" of modern architecture in Toronto, "providing a unifying focal point for Toronto's architects." ${ }^{4}$ By 1988, however, increasing membership meant the association was outgrowing its current location. Many interior renovations to accommodate administrative and archival expansions had compromised Parkin's open plan to the extent that original design intentions and aesthetics were no longer perceivable. ${ }^{5} \mathrm{~A}$ program for the new headquarters was planned to provide more offices, more meeting rooms, and more exhibition spaces. Additionally, making the headquarters less Toronto-focused and more accessible to members from across the province was crucial. This imperative was supported by a new site close to the 401, 404, and Don Valley highways, and all Ontario architects were invited to submit a proposal to the design competition. Sixty-five anonymous submissions were received by the five-member jury consisting of three architects, Patricia Patkau, Victor Marius Prus, and Gustavo da Roza, the Director of the OAA Brian Parks, and architecture critic Christopher Hume, who unanimously awarded the commission to Ruth Cawker Architect (fig. 2). ${ }^{6}$

Cawker's design embraced the association's desire for visibility and accessibility. Situated on the crest of a slope, the building was a prominent mark on the horizon, visible from the highway both into and out of Toronto. From the entrance to the site, a curving driveway wound around to a parking area set among slim pilotis supporting the main spaces of the building. The form and organization of the administration, meeting, and exhibition areas were composed of an assemblage of boxes, some glass and some solid, at the centre of which was a double-height mezzanine opening onto an outdoor courtyard at the second level. The most striking feature of the building was a wing-like steel structure floating above the roof, described by OAA member Macy Dubois as giving the design "a positive aura of radiating energy" that announced its landmark status. ${ }^{7}$ While some critics of the new OAA headquarters lamented its lack of progressive response to energy and environmental 
concerns, most were taken by the building's sense of lightness, and confirmed it met the OAA's aims of efficiency, access, and innovation. ${ }^{8}$

Notable for its significant design achievements, the OAA headquarters at 111 Moatfield Drive also holds a place in Canadian architectural history for the attention it focused on Ruth Cawker. While the design was the outcome of a team effort by Michael McColl, Willa Wong, Cheryl Kowaluk, Goran Milosevic, and Jonathon Crinion, as the principal architect and namesake of her firm, Cawker became something of an ambassador for women in architecture. Recalling how she was contacted almost weekly to speak on a range of subjects by both the architectural and popular press, Cawker noted that she "was in fact almost like a poster girl for women in architecture." 9 (fig. 3) Significantly, her experience signalled that women working in architecture were on the rise, occupying positions of leadership and influence. In the year prior to the competition, for example, the OAA created the $G$. Randy Roberts Service Award to acknowledge women architects for their exceptional contributions to the profession. Jeanne Arnold, a member of the OAA since 1963, was the first recipient of the award in 1989. ${ }^{10}$ Other competition entries for the new headquarters confirmed this trend, such as that of Brown and Storey Architects, a partnership founded in 1981 by Kim Storey and James Brown. In the same year as the OAA competition, Kuwabara Payne McKenna Blumberg Architects won a national competition to design Kitchener City Hall; at the time two of the four principals were women. ${ }^{11}$

As part of their investigation into the history of the building, the MSoA team interviewed Cawker about her experiences working on the OAA headquarters. ${ }^{12}$ She explained: "there was a willingness to do something exceptional, as not many buildings at that time were designed by a firm in which the principal architect was a woman." ${ }^{13}$ Cawker's comment reminds us of the OAA's practice of using their headquarters as landmarks in architectural history. While it was not the intention, arguably, when Cawker won the 1989 competition, the profession was eager to mark an architectural milestone. The production of the new headquarters became a venue to publicize the contributions of women to the profession. Importantly, the headquarters building, the competition, the OAA, and Ruth Cawker were tied in a uniquely visible way to the history of women in architecture in Canada.

\section{SOCIAL ISSUES OF GENDER INEQUITY IN THE PROFESSION}

Given that Cawker's experience working on the headquarters was now almost thirty years old and that she was not involved in the proposed retrofit, the MSoA team wondered how it resonated with the contemporary experiences of women in architecture. As part of our research, we collected numerous examples of significant steps made toward gender parity in the architectural profession. ${ }^{14}$ For instance, Chicago-based firm Studio Gang, headed by Jeanne Gang, discovered a small gender wage gap in 2017 and closed it in 2018; Boogertman + Partners, Africa's largest architecture practice, has acknowledged publicly that they will address the pay gap; and, in March 2019, Mumbai-based firm Morphogenesis reported a gender pay gap in favour of its women employees..$^{15}$ Our team also found evidence of gender discrimination deeply embedded in professional traditions, practices, and design. A survey of women architects in Canada by BEAT (Building Equality in Architecture Toronto) reported that "things are improving at a glacial pace and larger practices effectively have a glass ceiling in place. ${ }^{16} \mathrm{As}$ of 2017 , the ratio of men and women enrolled in architectural education programs in Canadian schools achieved parity, yet, in professional practice only 28.9 percent of all architects nation-wide were women. ${ }^{17}$ Somewhere between receiving a degree and professional registration, women were leaving the profession, according to marked trends in the Canadian, American, British, and Australian contexts. Several studies, including Annmarie Adams and Peta Tancred's "Designing Women" (2000) and Despina Stratigakos's Where Are the Women Architects? (2016), explore the diverse and complex reasons for the disparity of women in architectural professions. ${ }^{18}$ According to Stratigakos, "[i] $\mathrm{n}$ terms of job opportunities, pay equity, mentoring, and promotion, the deck is stacked against [women]."19 The number of women in the profession does not match the number of women graduating from architecture schools. This disparity is slowly closing, and one of the contributing factors is mentorship. Cawker acknowledged that both male and female mentors were crucial to her development in the profession, and that she continued to foster young women through the steps to licensure and practice within her own architectural office..$^{20}$ Mentorship is equally important in schools of architecture, and significantly, within the architectural studio.

\section{MAKING GENDER INEQUITY VISIBLE THROUGH DESIGN-BUILD PEDAGOGY}

While the profession continues to evolve, gender discrimination continues to flourish in the workplace, and as educators of future professionals, schools of architecture have a responsibility to make gender inequity a priority. One part of this process is to recognize disparities in the curriculum with regards to architecture's 
discriminatory system. Perhaps more important is to ask how architectural design education itself can be used to engage students with gender inequity in the architectural profession.

Architectural education happens primarily through two pedagogical methods. In the first, students are required to take courses in technical, professional, and architectural history and theory, which follow topics such as structural engineering principals, mechanical systems design, and the history of architecture and design theory. Most of these courses are exclusively taught in a traditional classroom/ auditorium setting, where students learn about gender and racial discrimination in architecture. The second pedagogical model is the design studio. Students are taught design processes through an individual desk-based and media-driven approach utilizing drawing, models, and digital tools. A simple diagram of the pedagogical arrangement would locate the design studio at the centre, surrounded by the classroom/auditorium courses with information flowing toward the core. ${ }^{21}$ The two models are different enough in their approach and learning experiences that students struggle to translate the critical knowledge learned in the classroom to the design studio. In both cases students rarely encounter the built environment as discrimination in action. ${ }^{22}$ The intent here is not to devalue these settings as venues for teaching social justice and critical histories; the dissemination of research, social critique, and non-canonical histories in the classroom is crucial to exposing inequity and creating safe spaces for students to learn and voice their difference from normative values and histories. ${ }^{23}$ What is at stake, however, is finding a pedagogical approach that aids students in their translation of the critical knowledge learned in the classroom to architectural design strategies. The design-build approach, illustrated here through the Glass Ceiling installation, offers a good example.

MSoA's curriculum is framed by a number of mandates that are intended to coalesce in a culture of social innovation: sustainability and wellness, community outreach, indigenous knowledges, advanced wood technology, and design-build learning. Of specific interest here is MSoA's designbuild mandate. In architectural education, design-build is a pedagogical approach that is an addition to desk-based design studio where students design projects, small and large, simple and complex, in the studio environment, and then construct the project at 1:1 scale. Designbuild aims to foster the development of skills based in practice such as collaboration, fine craft, and project management, and to explore architecture's capacity for social innovation. These dual goals are broadly understood to have found their way into architectural education through the educational manifesto of the Bauhaus (1919-1933). According to Greig Crysler, Bauhaus founder, Walter Gropius, during his time teaching at Harvard, proposed the role of the architect as "synthesizer and technician of need." ${ }^{24}$ Gropius's concept of integrationism rejected "isolated emphasis on single buildings and encouraged interdisciplinary collaborations with sociologists and others concerned with the study of society." 25 Branislav Foli, Saja Kosanovi, Tadej Glažar, and Alenka Fikfak, in their investigation of recognized design-build educational practices in North America, Central and Northern Europe, note that most contemporary design-build programs draw from methods used at the Bauhaus. Using perhaps more contemporaneous language, the Bauhaus's "experiential education," they posit, "was firmly connected to social agenda and technological experimentation so that their interlacing became of primary importance." 26 The design-build approach is firmly situated within the highly regarded field of "experiential learning."

Why position the experiential capacity of design-build pedagogy as a unique way to explore the notion of social innovation, and specifically gender inequity? In the built environment discrimination happens at 1:1-it is experiential. Designed spaces have an effect that arises out of cognitive interpretations of historical allusions, meanings, and aesthetics, as well as the body's somatic responses to a building or place. In her book Places of Learning: Media Architecture Pedagogy, Elizabeth Ellsworth explores the potential of using the built environment as a site of knowledge production. She explains: "like media and architecture, pedagogy [can involve] us in experiences of the corporeality of the body's time and space... experience arises out of an assemblage of mind/brain/body." Ellsworth posits that experiential learning (non-cognitive experiences or sensations) is underutilized, yet it plays a significant role in the acquisition and production of knowledge. ${ }^{27}$ Bodies learn by doing things. Good examples are driving a car or riding a bike-that is, learning experiences unique to the action of doing. It would be difficult to learn how to ride a bike by watching a video. Ellsworth is proposing educators to tap into this, to use the capacity for the body/mind to learn through the process of making.

Presenting students with a question, such as how the built environment operates with discrimination, asks them to further examine their personal and historical experiences with the built environment. Through this process, students explore experiences of movement in time and space (shifting directions, views around corners), light (the different feeling of 


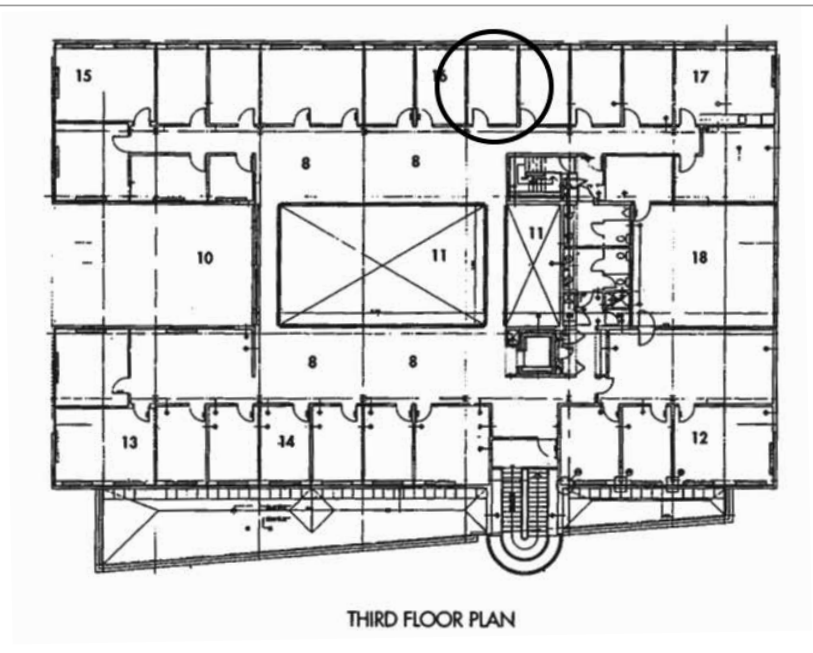

FIG. 4. THIRD FLOOR PLAN OF THE OAA HEADQUARTERS IN 1989. THE BLACK CIRCLEAUTHORS ADDITION—INDICATES THE OFFICE IN WHICH THE GLASS CEILING WAS INSTALLED DURING THE MOVE: BIG INSTALLATION PARTY. THE BRIDGE ACROSS THE DOUBLE-HEIGHT VOLUME GAVE DIRECT ACCESS TO THE FLOOR IN FRONT OF THE INSTALLATION. | DRAWING COURTESY OF THE CANADIAN ARCHITECT, NOVEMBER 1992, P. 17.

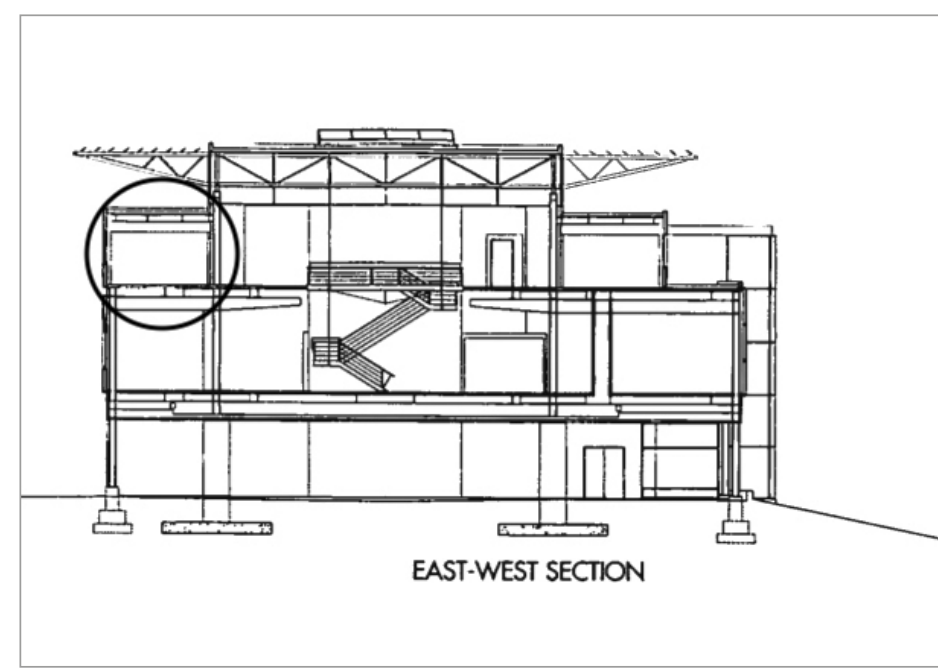

FIG. 5. SECTION THROUGH THE NEW OAA HEADQUARTERS IN 1989 SHOWING THE STAIR GIVING ACCESS TO THE THIRD FLOOR. THE BLACK CIRCLE—AUTHORS ADDITION—INDICATES THE OFFICE IN WHICH THE GLASS CEILING WAS INSTALLED DURING THE MOVE: BIG INSTALLATION PARTY. | DRAWING COURTESY OF THE CANADIAN ARCHITECT, NOVEMBER 1992, P. 16. a room from day to night), scale (the effect of the height or width of a room), and encounters with difference (how these experiences can differ amongst genders). The experiential approach of design-build encourages students (and teachers) "to confront their experiences within different systems of subjection on a personal level [in the] everyday." 28 In the process, the accumulation of knowledge is produced through a complex collective of subjectivities and historical encounters with the built environment. When students research and create at $1: 1$, they engage with the somatic experiences of the built environment, thereby exposing themselves to the corporeal operations of discrimination. Already scaled and materialized, these corporeal architectural encounters are immediately translatable to design. The Glass Ceiling installation is the outcome of an exploration into design-build's capacity to incorporate, and ultimately draw attention to, the issue of gender inequity in architecture.

\section{INSTALLATION DESIGN AND EXPERIENCE}

The brief for MOVE called for the installations to be exhibited in one of three spaces: the atrium, a large office, or a small office. The MSoA design group chose the small office as it was a manageable scale in which to manifest an immersive or experiential environment (fig. 4). Importantly, the room itself provided architectural components-door, window and ceilingthat we could draw upon to offer our interpretation. These elements provoke cognitive interpretations of buildings through use and meaning that are at once symbolic and actual. References to these elements appear in all means of cultural production, from literature to film. Doors, for example, create access to a space, and are symbolic portals to other realms. Windows frame a view, and have been deployed as an allegory for one's views, thoughts, and desires. ${ }^{29}$ Equally, through manipulation of colour, view, and angle, for example, architectural elements can affect experiences in time and space. The built environment is embedded with information, learned over time and through use, as metaphor, allegory, and symbolism. Exaggerated scale of buildings or monuments, for instance, can belittle a subject. Equally, physical and symbolic architectures, and associated learned behaviours can be powerful sites to transgress normative spatial regimes. ${ }^{30}$ In terms of our installation, the glass ceiling offered an architectural metaphor for an unseen, yet unbreachable barrier keeping women from rising beyond a certain level in the professional hierarchy. ${ }^{31}$ The Glass Ceiling installation proposed that by making adjustments to, and thereby reimagining the architectural norms of an office in the OAA building, we could activate a symbolic "office of architecture," and in so doing, tell the traditionally gendered story of architecture through a different lens. 


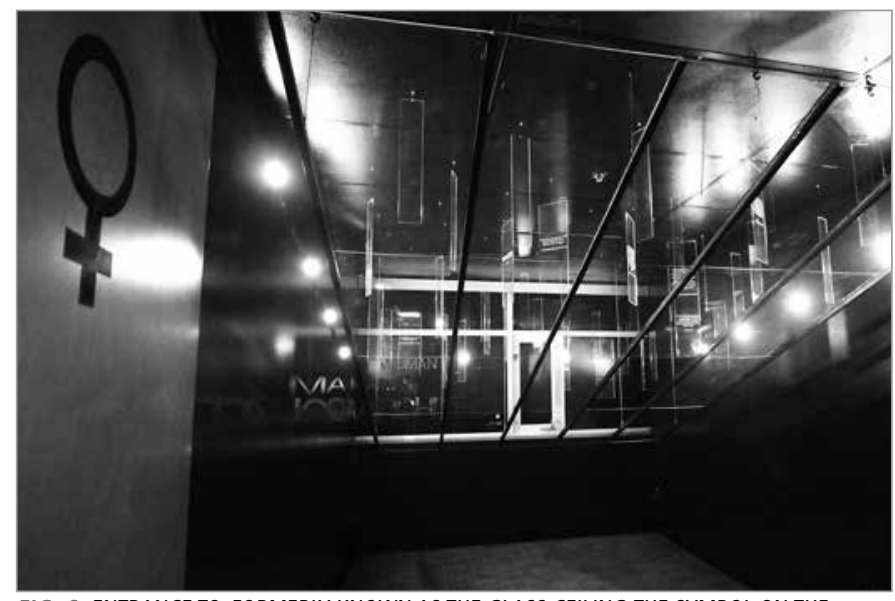

FIG. 6. ENTRANCE TO FORMERLY KNOWN AS THE GLASS CEILING. THE SYMBOL ON THE DOOR AND THE SLOPED CEILING WITH ACRYLIC PANELS ABOVE ARE VISIBLE IN THIS IMAGE. | CHRIS BAZII, SEPTEMBER 15, 2017.

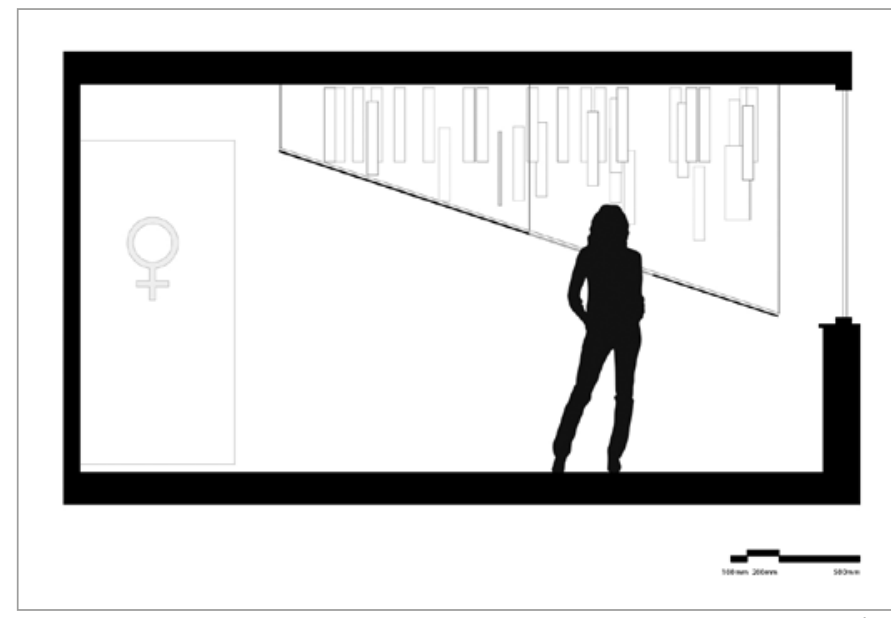

FIG. 8. SECTION THROUGH THE INSTALLATION FORMERLY KNOWN AS THE GLASS CEILING. DRAWN BY JEREMY UPWARD.

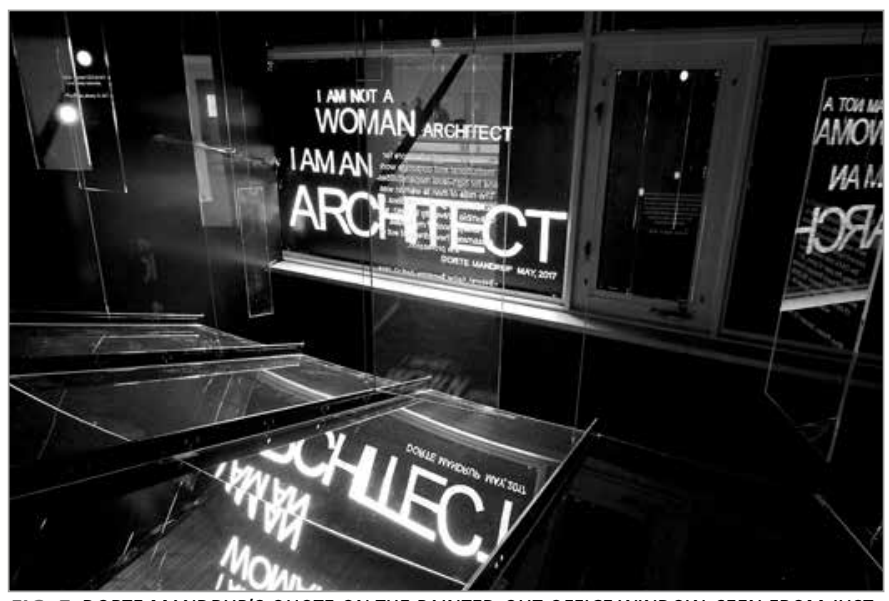

FIG. 7. DORTE MANDRUUP'S QUOTE ON THE PAINTED-OUT OFFICE WINDOW, SEEN FROM JUST ABOVE THE CEILING THROUGH THE ACRYLIC PANELS. | CHRIS BAZIW, SEPTEMBER 15, 2017.

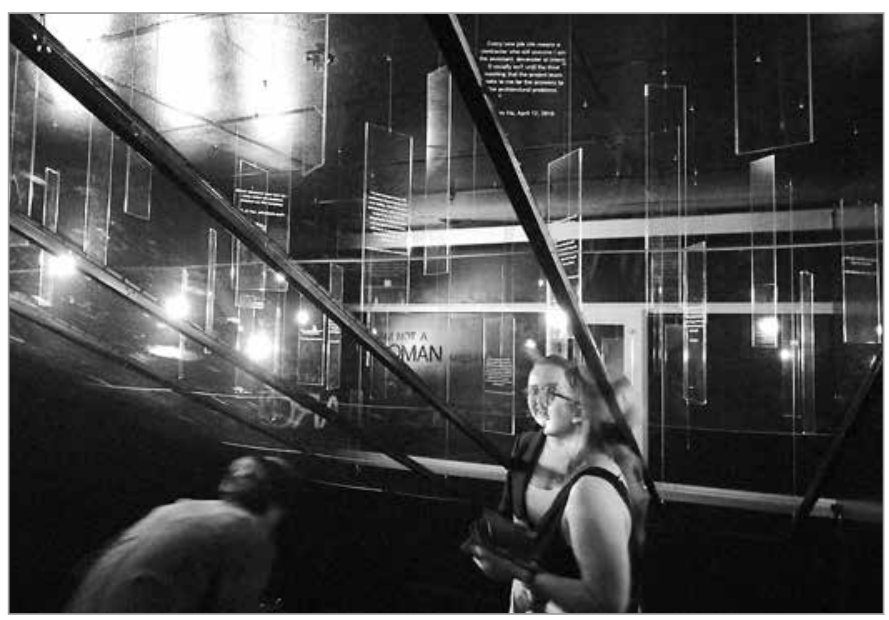

FIG. 9. IN THIS IMAGE OF FORMERLY KNOWN AS THE GLASS CEILING, WE CAN SEE HOW THE CEILING FORCED VISITORS TO CROUCH UNCOMFORTABLY TO FIND THEIR WAY TO THE OPENING. | CHRIS BAZIW, SEPTEMBER 15, 2017.
The only way to move from floor to floor at the event was via the building's feature stair located directly opposite the room with the MSoA installation (fig. 5). Visitors approached the Glass Ceiling from the top of the stair, and entered through the office's wooden door which had been emblazoned with a black Venus symbol signalling that the space was gendered female (fig. 6). Once inside, the walls and ceiling covered by high-gloss black paint receded, faintly shimmering from the glow of fluctuating multicoloured lights. Inside, the architectural elements that gave form to the office were rendered opaque. The window opposite the entrance was painted over. Cut out of the paint on the window's surface was a quote by Danish architect Dorte Mandrup, "I am not a woman architect, I am an architect." ${ }^{32}$ The painted-over window implied that one's view (or one's desires represented allegorically by the window) was obscured. Mandrup's quote disrupted the limitations implied by the paint, carving into it an ambition, and a view to the lights of the city outside (fig. 7).

From the doorway, visitors were confronted by the glass ceiling that filled the office from wall to wall. Comprised of nineteen acrylic sheets suspended on T-bar ceiling hangers and aircraft cables, the installation hung below the office's original ceiling at an angle so that the lowest point was opposite the entrance 


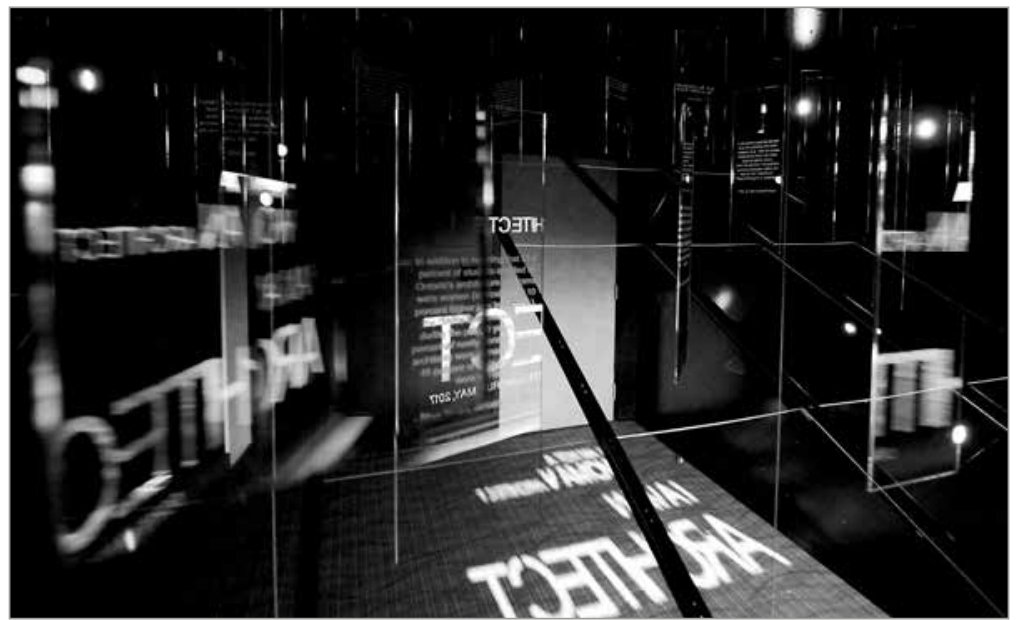

FIG. 10. THIS IMAGE OF FORMERLY KNOWN AS THE GLASS CEILING REVEALS THE VIEW LOOKING BACK UP THE CEILING ONCE VISITORS HAVE FOUND THEIR WAY THROUGH THE OPENING. | CHRIS BAZIW, SEPTEMBER 15, 2017.

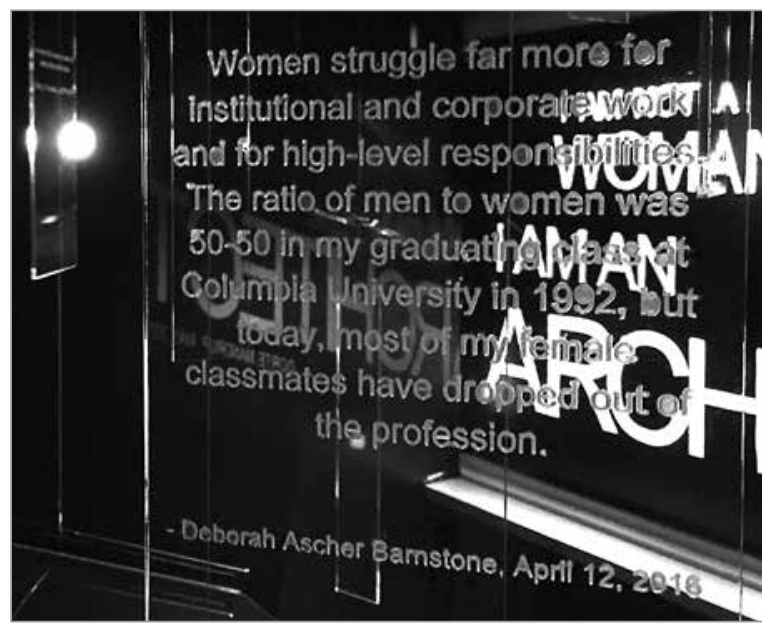

FIG. 11. IMAGE OF ONE OF THE QUOTES ETCHED INTO THE ACRYLIC PANELS HUNG ABOVE THE CEILING. | CHRIS BAZII, SEPTEMBER 15, 2017. (fig. 8). Above the glass ceiling, quotes laser-etched into acrylic rectangles spun slowly, rendered visible by the multicoloured lighting. Just slightly off centre and located where the sloped glass ceiling measured four and a half feet from the floor, one panel was left empty. Visitors seeking to view the quotes searched across the ceiling's reflective surface to find the opening. Once discovered, the slope of the ceiling forced them to crouch slightly as they moved toward the portal, imposing the frustrating constrictions of the glass ceiling on them (fig. 9).

Making their way through the opening in the ceiling, visitors now experienced the acrylic sloping upward, serving as a reminder that once a woman breaks through the ceiling, she must continuously validate her position (fig. 10). Here the ceiling became an allegory for the experience of women who have breached the unbreachable. Cawker, for example, having won the prestigious OAA headquarters architectural competition, argues it was much more difficult to substantiate her competency as a woman building a high-profile project then if she had been a man. ${ }^{33}$ She had broken through the glass ceiling, yet she still had to prove herself in ways she did not believe her male counterparts did. Hanging just above the inclined surface, the laser-etched quotes by contemporary women architects voiced small ongoing trials that build over time and can end up driving women from the profession (fig. 11), for instance, a quote from Vietnamese American architect Yen $\mathrm{Ha}$ read: "Every single day I have to remind someone that I am, in fact, an architect. And sometimes not just an architect, but the architect." ${ }^{34}$ In the background, sound clips of Ruth Cawker, taken from an interview with members of the design team a few weeks before the exhibition, described her own journey as a successful woman architect and offered advice to the next generation of women architects.

I didn't want people to think of me as a woman architect, I wanted to be thought of as an architect, plain and simple . . today, I think quite differently about it. When I look back, it was, in fact, a struggle-a struggle to be considered equally competent. I feel, today, it's more important than ever not to undermine the importance of being a woman in architecture, I feel the place in history for women architects is yet to be claimed. ${ }^{35}$

In combination, the glittering quotes etched into the acrylic and the sound of Cawker's voice were a collective verification of so many individual stories. Visitors who wanted to view the quotes had to actively pursue what was partially obscured by the installation itself. The installation compelled viewers to expend physical, emotional, and cognitive efforts to access the material, with the hope of implicating them in sensations and movements that alluded to the histories, knowledges, and ongoing experiences of women in architecture. ${ }^{36}$

Ellsworth explains that "architectural spaces and mediated cityscapes [can] emphasize non-cognitive processes and events such as movement, sensation, intensity, rhythm, passage, and selfaugmenting change," with pedagogical intent. ${ }^{37}$ In the Glass Ceiling, the sense of being drawn through experiences and processional pathways that modulated intensities through physical and sensorial choreography was meant to affect 
visitors' emotions-inviting a resonance between emotions and ideas. ${ }^{38}$ Being drawn into the office, puzzling one's way to an opening and breaking through the metaphoric surface of the glass ceiling, proposed that it was a transgressable barrier, yet a barrier still habituated by conventional ways of perceiving, thinking, and being in the world. Making use of seemingly benign architectural elements, the design of the installation broke with the conventions of office spaces. Through a displaced ceiling, elusive edges, explicit rather than implied gendering, and a message where a window should be, the asymmetrical intervention disrupted habitual ways of reading buildings. The MSoA team's design and installation of the Glass Ceiling was led by the idea that making discrimination visible by giving it a material presence makes it harder to ignore. The MOVE event hosted hundreds of OAA members, and non-member friends and students from Ontario's four schools of architecture. The Glass Ceiling was the only installation of the evening that was a reminder of gender disparity and we hope the visitors will talk about the experience of the Glass Ceiling by taking it with them to the office and into the design studio.

\section{CONCLUSION}

Finding methods and approaches to translate critical cultural theory to design pedagogy is challenging but essential. The pedagogical potential in the Glass Ceiling project was in the attention it focused on the relationship between historical architectural narratives and students' present and future entanglements with gender discrimination. Collaborating on the design and construction of the installation fostered discussions that led students to consider how different their architectural futures will likely be based on their gender. It drew attention to the daily discrimination female architectural graduates face as they begin their careers: the small everyday hurdles that women in architecture are challenged with, endure, and overcome, and the kinds of experiences hidden to most of their male counterparts. In this way, the project encouraged students to implicate themselves in architectural histories by coming to understand their role in larger political and social processes; it also invited consideration of the ways in which architectural practice and design have traditionally marginalized and made such histories invisible. Chris Baziw, Matt Hunter, and Jeremy Upward, for example, each noted that before they started working on the project, they were completely unaware that a woman's experience in the profession would be so significantly different than their own. ${ }^{39}$

Importantly, the project explored how architectural design can unearth histories of marginalization by deploying the built environment itself to materialize a story of gender inequity in architecture. Working through this problematic in relation to the design and construction of the installation meant that students resolved aesthetic and technical issues with the design relying on experiences from their own subject position. Simply, "the nuts and bolts" of the exhibition, its materiality, became the medium through which students expressed understandings of gender disparity. As future architects, it is crucial for students to develop the ability to critically engage with normative social structures through design. The thematic of gender diversity thus encouraged the team to push beyond comfortable subjectivities and implicate themselves as well as the built environment in gender discrimination, making, as Greig Chrysler explains, "the personal cultural and the cultural personal."40 Situating the group in the dynamic physical and material process of creating and successfully completing the installation meant working together in ways that fostered empathy for the experience of the other-through the experience individuals came to understand their own subject position in architecture in a new way. ${ }^{41}$ Examining the issue of gender discrimination from different subjectivities meant the team collaborated on research, design concepts, and solutions that are normally relegated to the realm of the other, provoking the group to ask "how can men and women work together to stop gender discrimination?"42

The Glass Ceiling was an incontrovertible reminder that efforts made by women to achieve equal footing in the profession are ongoing. The setting for the MOVE event, a retrofit of the 1989 competition-winning design signalling women's increasing influence and leadership in the profession, was a poignant opportunity to draw attention to contemporary machinations of gender inequity in architecture. Importantly, the OAA headquarters is the symbolic and actual site of the profession and its ambitions. By assembling Ontario's schools of architecture and architectural practitioners in that building to celebrate the renovationand the future of the profession-MOVE created an opening for the exchange of experiences and ideas. In that setting the Glass Ceiling operated in a temporary fashion on the edges of architecture and pedagogy, not fully engaged in either. That aspect allowed students to observe reactions to their design from visitors rather than professors, which concretized their accomplishments in an everyday social context. The project's critique of gender discrimination then was not an abstraction thrust upon them by a critical teacher, but a material and cultural reality of their own making. Ultimately, much potential lies in small, inexpensive, 
nimble interventions that respond to and reinterpret architectural elements experienced most intimately through everyday experiences, such as doors, walls, ceilings, and windows. Utilizing these as our tools we can take a traditional story and tell it through different means, and reimagine it so that it becomes something new.

\section{NOTES}

1. The project, ongoing as of this publication, is led by Fujiwara in association with Sustainable EDGE, Gottesman Associates, and Transpolar. Sustainable EDGE brings a specialization in green design and ecological engineering; Gottesman is a lighting design firm; and Transpolar Technology Corporation is an information technology consulting enterprise.

2. The call for installation proposals for MOVE did not make note of a specific theme exhibitors were to address, nor did it ask teams to consider the title itself in their proposals. The title seemed simply connected to the fact that the OAA would be moving out of its headquarters during the renovation. Installations on the night of the event varied from explorations of material expression, to geometrically arranged lighting experiences, to an upside-down room. MSoA, however, wanted to make a connection between the title and their installation, inspired by the idea that MOVE implies action, or to act on a thing in a way that changes its position.

3. The team was assembled on a volunteer basis by students available to work at the school during the summer months, outside of the typical school year.

4. Ontario Association of Architects, 2017, 50 Park Road (Former OAA Headquarters) (Built: 1954, Renovation: 1992, 2009), November 8 , n.p., [http://www.oaa.on.ca/bloaag-detail/50Park-Road-(Former-OAA-Headquarters)(Built:-1954,-Renovation:-1992,-2009)/463], accessed January 4, 2019.

5. Id.

6. Ontario Association of Architects, By Ontario Association of Architects, n.d., n.p., [http:// oaa.on.ca/professional\%20resources/sustainable $\% 20$ design/hq-article/Buildings-evolve--the-OAA-Headquarters-is-no-exception/1], accessed March 25, 2019.

7. Dubois, Macy, 1992, "Wings over Don Mills: Ontario Association of Architects
Headquarters," The Canadian Architect, November, p. 20.

8. B.L., 1992, "Wings over Don Mills: Ontario Association of Architects Headquarters," The Canadian Architect, November, p. 12-20.

9. The interview was carried out by Thomas Strickland, September 9, 2017. Cawker is currently a principal at the firm Atelier Baraness + Cawker, based in Nice, France.

10. Association of Architects, 2017, Spotlight on OAA Awards - Female Recipients of OAA Service Awards since 1988, January 5, n.p., [https://www.oaa.on.ca/ bloaag-detail/Spotlight-on-OAA-Awards--Female-Recipients-of-OAA-Service-Awardssince-1988/408], accessed March 15, 2019.

11. Black, Karen, 1989, "Kuwabara Payne McKenna Blumberg Wins Kitchener City Hall Competition," Perspective: Newsletter of the Ontario Association of Architects, vol. 3, no. 3, p. 1-12, at p. 12

12. Ruth Cawker, interview, 2017.

13. Id.

14. See: Ontario Association of Architects, Fall BLOAAG Series: Women in Architecture, Ontario, [https://www.oaa.on.ca/bloaag?t ag =WOMEN+IN+ARCHITECTURE], accessed March 15, 2019.

15. Block, India, 2019, "Morphogenesis Celebrates 'Gender-positive' Pay Gap," Dezeen.com, March 15, n.p., [https://www.dezeen. com/2019/03/05/morphogenesis-genderpositive-pay-gap-women-architects/], accessed March 20, 2019. See also: Gibson, Eleanor, 2018, "Jeanne Gang Closes Gender Pay Gap at Her Architecture Firm," Dezeen. com, July 9, n.p., [https://www.dezeen. com/2018/07/09/jeanne-gang-closes-genderpay-gap-studio-gang/], accessed March 20, 2019; and Ravenscroft, Tom, 2018, "Africa's Largest Architecture Practice Pledges to Move the Needle on Gender Diversity," Dezeen. com, April 3, n.p., [https://www.dezeen. com/2018/04/13/boogertman-partners-africaarchitects-move-the-needle-gender-diversity/], accessed March 20, 2019.

16. BEAT, 2017, "Female Architects Respond to Gender Survey 'It's Getting Better but far too Slowly,'" Building Equality in Architecture Toronto, November 18, n.p., [http://www. beatoronto.com/blog/2017/11/18/femalearchitects-respond-to-gender-survey-itsgetting-better-but-far-too-slowly], accessed March 21, 2019).
17. Phillips, Rhys, 2017, "Because it's 2017: Gender Diversity in Canada's Architecture Profession," Canadian Architect, January 12, n.p., [https:// www.canadianarchitect.com/gender-diversity-in-canadas-architecture-profession/], accessed January 4, 2019.

18. Adams, Annmarie and Peta Tancred, 2000, "Designing Women": Gender and the Architectural Profession, Toronto, University of Toronto Press; Stratigakos, Despina, 2016, Where Are the Women Architects?, Princeton, Princeton University Press.

19. Stratigakos, Where Are the Women Architects?, p. 35. Her findings are echoed in testimonials of women architects recorded in several stories featured in news media. See for instance, Wainwright, Oliver, 2018, "Snubbed, Cheated Erased: The Scandal of Architecture's Invisible Women," The Guardian, n.p., [https:// www.theguardian.com/artanddesign/2018/ oct/16/the-scandal-of-architecture-invisiblewomen-denise-scott-brown?CMP=Share AndroidApp_Messenger], accessed January 12, 2019; Besner, Linda, 2017, "Female Perspectives on Design and What We Lose without It," Azure Magazine, September 25, n.p., [https://www.azuremagazine.com/article/ design-lose-female-perspectives-not-integral-part-built-reality/], accessed January 12 , 2019; Howorth, Dan, 2017, "American Women in Architecture Weigh in on 'Female Architect' Debate," Dezeen.com, July 13, n.p., [https:// www.dezeen.com/2017/07/13/americanwomen-architecture-reactions-dorte-mandrup-opinion-female-architect/], accessed September 9, 2018.

20. Cawker, interview, 2017. Her list of mentors includes Marianne McKenna and Shirley Blumberg, principals in KPMB Architects of Toronto, and Kevin Garland, principal at Diamond and Schmitt Architects of Toronto.

21. Crysler, Greig, 1995, "Critical Pedagogy and Architectural Education," Journal of Architectural Education (1984-), vol. 48, no. 4, p. 209-210. Studio and classroom/auditorium arrangements are examples of what Chrysler describes as the transmission model, where the teacher is the primary expert and discourse on the subject of gender inequity in the built environment is largely predicated on the knowledge of the individual.

22. Crysler, id., p. 214. See also: Ellsworth, Elizabeth, 1992, "Why Doesn't This Feel Empowering? Working through the Repressive Myths of Critical Pedagogy," in Carmen Luke and Jennifer Gore (eds.), Feminisms and Critical Pedagogy, New York, Routledge, p. 90-119, at p. 102. 
23. Dutton, Thomas, 1991, "The Hidden Curriculum and the Design Studio: Toward a Critical Studio Pedagogy," in Thomas Dutton (ed.), Voices in Architectural Education. Cultural Politics and Pedagogy, New York, Greenwood, p. 175. See also Crysler, "Critical Pedagogy and Architectural Education," p. 212 and 214.

24. Crysler, id., p. 214.

25. Ibid.

26. Foli, Branislav, Saja Kosanovi, Tadej Glažar, and Alenka Fikfak, 2006, "Designbuild Concept in Architectural Education," Architecture and Urban Planning, September, p. 49-55, at p. 50 .

27. Ellsworth, Elizabeth Ann, 2005, Places of Learning: Media, Architecture, Pedagogy, New York, Routledge, p. 4.

28. Crysler, "Critical Pedagogy and Architectural Education," p. 214. See also Hanisch, Carol, 1970, "The Personal is Political," in Anne Koedt and Shulamith Firestone (eds.), Notes from the Second Year: Women's Liberation, New York, Radical Feminism.

29. Edward Morgan Forster's 1908 book, A Room with a View, is a poignant example of how architecture is deployed as allegory for lived experiences through which the built environment reciprocally acquires cultural capital.

30. Dovey, Kim, 1999, Framing Places: Mediating Power in Built Form, New York, Routledge, p. 11.

31. Federal Glass Ceiling Commission, 1995, Solid Investments: Making Full Use of the Nation's Human Capital, Washington, DC, US Department of Labor, November, p. 13-15. The document reference includes "minorities" in the description; for the sake of clarity, in this text we hone in on women.

32. Mandrup, Dorte, 2017, "I am not a female architect, I am an architect," Dezeen. com, May 25, n.p., [https://www.dezeen. com/2017/05/25/dorte-mandrup-opinioncolumn-gender-women-architecture-femalearchitect/], accessed January 14, 2019.

33. Cawker, interview, 2017

34. Yen $\mathrm{Ha}$, quoted in Robin Pogrebin, 2016, "I Am Not the Decorator: Female Architects Speak Out," The New York Times, April 12, n.p., [https://www.nytimes.com/2016/04/13/ arts/design/female-architects-speak-out-onsexism-unequal-pay-and-more.html], accessed January 14, 2019

35. Cawker, interview, 2017.
36. Ellsworth, Places of Learning, p. 42

37. Id., p. 6.

38. Id., p. 21.

39. Chris Baziw, Matt Hunter, and Jeremy Upward, in conversation with Thomas Strickland, August 25, 2018.

40. Crysler, "Critical Pedagogy and Architectural Education," p. 215.

41. Marina Schwellnus, in conversation with Thomas Strickland, May 4, 2018.

42. Id 